\title{
Salivary IgA antibodies to cyclic citrullinated peptides (CCP) in rheumatoid arthritis
}

\author{
Anna Svärd, Alf Kastbom, Yngve Sommarin and Thomas Skogh
}

\section{Linköping University Post Print}

N.B.: When citing this work, cite the original article.

Original Publication:

Anna Svärd, Alf Kastbom, Yngve Sommarin and Thomas Skogh, Salivary IgA antibodies to cyclic citrullinated peptides (CCP) in rheumatoid arthritis, 2013, Immunobiology, (218), 2, 232-237.

http://dx.doi.org/10.1016/j.imbio.2012.04.011

Copyright: Elsevier

http://www.elsevier.com/

Postprint available at: Linköping University Electronic Press

http://urn.kb.se/resolve?urn=urn:nbn:se:liu:diva-90205 


\section{Elsevier Editorial System(tm) for Immunobiology}

Manuscript Draft

Manuscript Number: IMBIO-D-12-00064R1

Title: Salivary IgA antibodies to cyclic citrullinated peptides (CCP) in rheumatoid arthritis

Article Type: Research Paper

Keywords: Citrullinated peptides, IgA, Rheumatoid arthritis, Saliva, Mucosal immunity

Corresponding Author: Dr. Thomas Skogh, MD PhD

Corresponding Author's Institution: Linköping university

First Author: Anna Svärd, MD

Order of Authors: Anna Svärd, MD; Alf Kastbom, MD PhD; Yngve Sommarin, PhD; Thomas Skogh, MD $\mathrm{PhD}$

Abstract: Circulating IgG anti-cyclic citrullinated peptide antibodies (CCP) are highly specific for rheumatoid arthritis (RA) and prognostic of poor outcome. Serum IgA anti-CCP occurs in a subset of IgG-positive cases and relates to still more aggressive disease. Mucosal IgA-class antibodies, however, are generally associated with anti-inflammatory actions and systemic tolerance induction. In the present study, unstimulated salivary samples from 63 patients with established RA and 20 healthy persons were analysed by enzyme-linked immunoassay for the presence of IgA anti-CCP antibodies. To ensure antigen specificity, IgA-reactivity with the corresponding uncitrullinated antigen, cyclic arginine peptide (CAP), was analysed and anti-CCP/anti-CAP ratios calculated. Retrospective data regarding disease activity and radiological outcome were achieved via medical records. Salivary IgA anti-CCP was found in 14/63 (22\%) patients and one (5\%) control (positive test = anti-CCP/anti-CAP ratio $>1.5$ ). Salivary IgA reactivity was dose-dependently inhibited by pre-incubation with soluble CCP to a degree strongly correlating with anti-CCP/anti-CAP ratio. In salivary IgA anti-CCP positive patients, joint erosions within 6 years of diagnosis was significantly lower $(\mathrm{p}=0.043)$, and at the time for diagnosis there was a trend towards lower erythrocyte sedimentation rate $(p=0.071)$ and $C$ reactive protein $(\mathrm{p}=0.085)$. Contrasting to circulating IgG and IgA anti-CCP, our results imply that salivary IgA antibodies may be associated with a less severe outcome of RA. Hypothetically, this relates to an anti-inflammatory and protective immunomodulating role of secretory IgA-class autoantibodies against citrullinated antigens presented at mucosal surfaces. 
Title:

Salivary IgA antibodies to cyclic citrullinated peptides (CCP) in rheumatoid arthritis

Short title:

Salivary IgA anti-CCP in RA

\section{Authors:}

Anna Svärd, Alf Kastbom, Yngve Sommarin, and Thomas Skogh

Corresponding author:

Thomas Skogh MD, PhD

Department of Clinical and Experimental Medicine, Linköping University, SE-581 85 Linköping, Sweden

E-mail: thomas.skogh@lio.se Telephone: +461030000Ｆax:+4613221357

\section{Co-authors addresses}

Anna Svärd, MD

Rheumatology Clinic, Falun Hospital, SE-791 82 Falun, Sweden.

Alf Kastbom MD, PhD

Department of Clinical and Experimental Medicine, Linköping University, SE-581 85 Linköping, Sweden

Yngve Sommarin $\mathrm{PhD}$

Euro-Diagnostica AB, Lundavägen 21, SE-212 24 Malmö, Sweden

\section{Key words}

Citrullinated peptides, IgA, Rheumatoid arthritis, Saliva, Mucosal immunity,

\section{List of abbreviations}

ACPA = anti-citrullinated protein/peptide antibody

CAP = cyclic arginine peptide

$\mathrm{CCP} \quad=$ cyclic citrullinated peptide

CIA = collagen-induced arthritis

CRP = C-reactive protein

DAS28 = 28-joint count disease activity score

$\mathrm{HAQ}=$ health assessment questionnaire

OD = optical density

$\mathrm{Pg} \quad=$ Porphyromonas gingivalis

RA = rheumatoid arthritis

$\mathrm{RF} \quad=$ rheumatoid factor

slgA $=$ secretory $\lg \mathrm{A}$

\section{COMPETING INTERESTS}

Yngve Sommarin is employed by EuroDiagnostica AB. 


\section{ABSTRACT}

Circulating IgG anti-cyclic citrullinated peptide antibodies (CCP) are highly specific for rheumatoid arthritis (RA) and prognostic of poor outcome. Serum IgA anti-CCP occurs in a subset of lgG-positive cases and relates to still more aggressive disease. Mucosal IgA-class antibodies, however, are generally associated with antiinflammatory actions and systemic tolerance induction. In the present study, unstimulated salivary samples from 63 patients with established RA and 20 healthy persons were analysed by enzyme-linked immunoassay for the presence of IgA antiCCP antibodies. To ensure antigen specificity, IgA-reactivity with the corresponding uncitrullinated antigen, cyclic arginine peptide (CAP), was analysed and antiCCP/anti-CAP ratios calculated. Retrospective data regarding disease activity and radiological outcome were achieved via medical records. Salivary IgA anti-CCP was found in 14/63 (22\%) patients and one (5\%) control (positive test $=$ anti-CCP/antiCAP ratio $>1.5)$. Salivary IgA reactivity was dose-dependently inhibited by preincubation with soluble CCP to a degree strongly correlating with anti-CCP/anti-CAP ratio. In salivary IgA anti-CCP positive patients, joint erosions within 6 years of diagnosis was significantly lower $(p=0.043)$, and at the time for diagnosis there was a trend towards lower erythrocyte sedimentation rate $(p=0.071)$ and $C$-reactive protein $(p=0.085)$. Contrasting to circulating $\lg G$ and $\lg A$ anti-CCP, our results imply that salivary IgA antibodies may be associated with a less severe outcome of RA. Hypothetically, this relates to an anti-inflammatory and protective immunomodulating role of secretory IgA-class autoantibodies against citrullinated antigens presented at mucosal surfaces. 


\section{INTRODUCTION}

The presence of circulating IgG class antibodies to citrullinated peptides (IgG-ACPA) is highly specific for rheumatoid arthritis (RA) and is associated with a more severe disease course and outcome (Forslind et al. 2004; Kastbom et al. 2004; van Gaalen et al. 2004; Huizinga et al. 2005; van der Woude et al. 2010). Thus, testing for lgGACPA has rapidly become routine in clinical investigation of patients with early arthritis. So far, the best documented ACPA test for clinical routine is IgG antibodies against the 'second generation' of cyclic citrullinated peptides (CCP). In a subset of IgG-ACPA positive patients circulating IgA-ACPA have been described, but the low sensitivity limits its diagnostic value (Verpoort et al. 2006; Verpoort et al. 2007; Svärd et al. 2008; Svärd et al. 2010). The prognostic value of serum IgA-ACPA has not been firmly established, but similar to rheumatoid factor (RF) of IgA-class (Houssien et al. 1997; Lindqvist et al. 2005; Berglin et al. 2006), a more severe disease has been described in IgA-ACPA positive patients (Verpoort et al. 2006; Verpoort et al. 2007; Svärd et al. 2008; Svärd et al. 2010).

Contrasting to $\lg G$-class antibodies, secretory $\lg \mathrm{A}(\mathrm{s} \lg \mathrm{A})$ antibodies are nonopsonising, non-complement activating and resistant to proteolytic degradation (Mestecky et al. 2007; Brandtzaeg 2010). At mucosal surfaces, slgA antibodies thereby play an important role for immune exclusion, i.e. an anti-inflammatory process whereby slgA-complexing of antigens, prevents their entry across the mucous membrane and promotes their silent excretion from the body (Stokes et al. 1975). T-cell dependent B cells (B2 cells) are responsible for high-affinity slgA antibody production leading to immune exclusion of pathogenic microbes and soluble potentially harmful antigens. Animal studies also implicate that CD5+ B1 cells in the 
gut can produce T-cell independent slgA antibodies, which are non-excluding and of low affinity. Such 'natural' slgA antibodies are believed to be of importance for symbiosis with commensal bacteria on mucous membranes in mouse and most likely also in man (Brandtzaeg 2010; Suzuki et al. 2010; Baumgarth 2011; Cerutti et al. 2011). Although transfer of macromolecular antigen across the gut to the systemic circulation is exceedingly small even in the absence of mucosal antibodies (Skogh 1982), passage of small antigenic degradation fragments may well occur, but also this is efficiently prevented by slgA antibodies (Skogh et al. 1983). Even in the case of antigen penetrance of mucous membranes, slgA may act anti-inflammatory, e.g. by preventing complement activation. Secretory IgA-antibody responses at mucosal surfaces are stimulated by transforming growth factor beta and take part in a Th3 type regulatory T-cell mediated immune response, promoting systemic tolerance in parallel with the mucosal anti-inflammatory antigen-targeting response (Weiner et al. 2011). It has long been known that such mucosal immunisation may induce systemic tolerance against delayed type of hypersensitivity reactions, whereas already established T-cell mediated inflammation is difficult to deviate by mucosal antigen challenge (Chase 1946; Mestecky et al. 2007). Mucosal immunisation to induce systemic tolerance and thereby prevent development of autoimmune diseases has been successfully demonstrated in several experimental animal models, including collagen-II (CII) induced arthritis (CIA).

This study was performed to determine if IgA-ACPA occurs in saliva of patients with an established clinical diagnosis of RA as a reflection of mucosal immunisation and, if so, to relate salivary IgA-ACPA to disease activity at the time for diagnosis and to erosive joint disease at follow-up. 


\section{MATERIALS AND METHODS}

\section{Patients}

In conjunction with planned visits to the rheumatology outpatient clinic in Falun, patients with a clinical diagnosis of RA were asked to participate in the study. 63 patients were enrolled during 2009 and 2010; 43 women and 20 men (median age $=64$, range 30-84 years). Fulfilment of the 1987 ACR and/or 2010 Euro-American classification criteria (Arnett et al. 1988; Aletaha et al. 2010) was assessed from data registered in the medical records; Among the 49 patients where such data were available, $96 \%$ of the cases could be classified as having RA; $80 \%$ according to ACR-87 and further $16 \%$ according the 2010 criteria). Two of the 49 patients (4\%) did not fulfil any of the above mentioned criteria. For the remaining 14 patients included in the study, the RA diagnosis had been made before 1990 or the patients had moved to the Falun region with an RA diagnosis established elsewhere, and sufficient data was lacking to allow classification according to the RA classification criteria. With no exception, however, the clinical diagnosis of RA had been settled by an experienced rheumatologist. The majority of the cases (83\%) were selected on the basis of a previous positive serum test for $\lg G$ anti-CCP, as we presumed that this would enhance the chance of finding salivary IgA anti-CCP ACPA. The patient characteristics at inclusion are summarised in Table 1.

Healthy controls were recruited among employees at the rheumatology unit $(n=20,16$ women and 4 men; median age=51, range 28-63 years).

\section{Autoantibody analyses}

Saliva was collected by 'passive drooling', with the donor leaning forward allowing saliva to drip via a funnel into a test tube placed on ice. Participants were asked to refrain from eating, drinking or smoking one hour before sampling. The samples were immediately centrifuged for 10 minutes at $5000 \mathrm{xg}$ to remove non-soluble material and the saliva was transferred to new test tubes and stored at $-80^{\circ} \mathrm{C}$ until analysis. 
Salivary IgA anti-CCP was analysed using a modification of an anti-CCP2 kit (CCPlus $\AA$, Euro-Diagnostica AB, Malmö, Sweden). After thawing, the saliva samples were centrifuged for $10 \mathrm{~min}$ at $15000 \mathrm{xg}$ to remove non-soluble material. The remainder of each centrifuged sample was diluted 1:20 using the kit diluent. As secondary antibody we used polyclonal rabbit IgG anti-human $\alpha$-chain antibodies conjugated with horse-radish peroxidase (HRP; DakoCytomation, Glostrup, Denmark) diluted 1:200 with the kit diluent. To evaluate the specificity of anti-CCP reactivity, plates coated with cyclic arginine peptide (CAP, Euro-Diagnostica) were used as control, following the same protocol.

Serum samples were analysed regarding $\lg G$ and $\lg A$ anti-CCP antibodies. IgG antibodies against the second generation CCP (CCPlus $\circledast$, Euro-Diagnostica) were analysed as part of clinical routine and $\lg \mathrm{A}$ anti-CCP antibodies were analysed using a modification of this assay as described previously (Svärd et al. 2008). A serum dilution of 1:100 was used, and as secondary antibody horse-radish peroxidase-conjugated polyclonal rabbit anti-human $\alpha$-chain antibody (same as above) diluted 1:2000 was utilised. Salivary samples from patients positive for lgG anti-CCP in serum were also tested for salivary $\lg G$ anti-CCP, but due to insufficient amounts of saliva, only 27 out of 42 samples were available for lgG anti-CCP analysis. The cut-off limit for serum IgG anti-CCP was $25 \mathrm{U} / \mathrm{mL}$ and for serum $\lg A, 25$ $\mathrm{AU} / \mathrm{mL}$ (corresponding to anti-CCP levels above the $99^{\text {th }}$ percentile among healthy blood donors). 


\section{Inhibition assays}

Inhibition assays were performed on 9 saliva samples with CCP/CAP ratio $>1.5$ and 8 samples with CCP/CAP ratio $<1.5$. Centrifuged saliva samples $(10$ minutes at $15000 \times \mathrm{g}$ ) were diluted with kit buffer with added soluble peptides (CCP and CAP respectively, Euro-Diagnostica) at final concentrations of $0-800 \mu \mathrm{g} / \mathrm{mL}$. After 30 minutes' incubation at room temperature the samples were analysed for IgA antiCCP as described above.

\section{Disease activity and outcome data}

Data regarding serum C-reactive protein (CRP), 28-joint count disease activity score (DAS28) based on erythrocyte sedimentation rate (ESR), swollen and tender joints and the patient's global assessment of average disease activity during the last week (Prevoo et al. 1995), the Swedish version of 'health-assessment questionnaire' (HAQ)(Ekdahl et al. 1988), and latex particle agglutinating rheumatoid factor (RF) were retrospectively obtained from the patients' medical records. Radiographic assessments were based on the written reports from an experienced radiologist, evaluating the presence or absence of erosions within 6 years of diagnosis.

\section{Statistical analyses}

Statistical analyses were performed using SPSS statistical software (version 15.0; SPSS, Chicago, IL, USA). Spearman's rho correlation coefficient was used to evaluate the correlation between IgA anti-CCP levels in serum and IgA anti-CCP/antiCAP in saliva, and also the correlation between the degree of inhibition achieved with soluble CCP and the anti-CCP/anti-CAP ratio. Fisher's exact test was used to compare the prevalence of positive IgA anti-CCP tests in the RA population to a 
positive test in the control population, to analyse occurrence of erosions in relation to anti-CCP/anti-CAP status and to test for differences in occurrence of circulating IgG anti-CCP, $\lg A$ anti-CCP and RF between patient groups positive vs negative for $\lg A$ anti-CCP in saliva. The Mann-Whitney U-test was used to test for differences in circulating levels of $\lg A$ anti-CCP, $\lg G$ anti-CCP, RF and disease activity variables comparing patients positive vs negative regarding salivary $\lg \mathrm{A}$ anti-CCP. 


\section{RESULTS}

\section{Salivary $\lg \mathrm{A}$ anti-CCP antibodies}

Analysis of salivary IgA anti-CCP antibodies by ELISA consistently gave high background optical density (OD) values in RA patients as well as in healthy controls (Mean OD 1.17 vs 1.16, $\mathrm{p}=0.96$ ). To evaluate the antigen specificity, OD values achieved by $\lg$ A anti-CCP ELISA were divided with the corresponding values for IgA anti-CAP. An IgA anti-CCP/anti-CAP ratio of $>1.5$ was considered positive and corresponded to the 95th percentile cut-off value among the 20 healthy subjects (one positive at an anti-CCP/anti-CAP ratio of 1.62). By this definition, 14 out of $63 \mathrm{RA}$ patients (22\%) tested positive for salivary $\lg A$ anti-CCP, as compared to one positive (5\%) among the 20 controls. IgG anti-CCP antibodies in serum were found in all patients testing positive for salivary IgA anti-CCP, compared to $80 \%$ in the salivary IgA anti-CCP negative group (statistically non-significant, ns). The corresponding figures regarding positive serum tests for $\lg \mathrm{A}$ anti-CCP were $50 \%$ in the salivary $\lg \mathrm{A}$ anti-CCP positive group and $28 \%$ in the salivary IgA anti-CCP negative group (ns) and for RF $92 \%$ in the salivary IgA anti-CCP positive group, compared to $73 \%$ in the salivary IgA anti-CCP negative group (ns). Among the 26 patients analysed for salivary IgG anti-CCP, all tested positive for serum IgG anti-CCP (range 40-2000 $\mathrm{U} / \mathrm{mL}$, median $450 \mathrm{U} / \mathrm{mL}$ ), but only one tested positive for salivary $\lg \mathrm{G}$ anti-CCP at a borderline value of $30 \mathrm{U} / \mathrm{mL}$ (serum level $2000 \mathrm{U} / \mathrm{mL}$ ). The background OD levels regarding $\lg G$ anti-CCP in saliva were consistently low (mean OD 0.011). As illustrated in Figure 1a, pre-incubation of the patient saliva samples with increasing amounts of soluble CCP assured the occurrence of CCP-specific reactions at anti-CCP/CAP ratios $>1.5$. Pre-incubation with CAP gave no inhibition whatsoever (Figure 1a). Saliva samples with ratios $<1.5$ were not inhibited by the 
CCP peptides (Figure 1b). There was a dose-dependent correlation (Rho $=0.81$, $\mathrm{p}<0.001$ ) between maximal CCP-mediated inhibition and anti-CCP/CAP ratio (Figure 2)

In $56(89 \%)$ of the patients X-ray examination of hands and feet had been undertaken within 6 years of established diagnosis. The last X-ray within 6 years was on average performed at 1.7 years (salivary $\lg A$-positive, $n=12$ ) and 2.1 years (salivary IgA-negative, $\mathrm{n}=44$ ) after diagnosis, with no statistical significance between the groups $(p=0.33)$. Twelve of the 56 patients $(21 \%)$ had salivary $\lg A$ anti-CCP antibodies (ratio $>1.5$ ), but only one of these $(8 \%)$ had bony joint erosions visible on X-ray. This can be compared with erosive disease occurring in 18/44 (41\%) of the patients lacking salivary IgA antibodies $(p=0.043)$ (Figure 3a). Similar, but nonsignificant, trends were seen regarding baseline levels of ESR and CRP, which were lower at the time for diagnosis among patients who tested positive regarding salivary IgA anti-CCP (mean ESR 18 vs $33 \mathrm{~mm} / \mathrm{h} ; \mathrm{p}=0.071$ and mean CRP 7 vs $13 \mathrm{mg} / \mathrm{L}$; $\mathrm{p}=0.085$ ) (Figure $3 b$ ). Differences regarding $\mathrm{HAQ}$ and DAS28 were not statistically significant ( 0.13 vs $0.88, \mathrm{p}=0.24$ and 3.61 vs $5.20 ; \mathrm{p}=0.341)$. 


\section{DISCUSSION}

Reports on mucosal autoantibodies in RA are scarce, but secretory IgA-RF has been described (Dunne et al. 1979; Elkon KB 1983; Chu et al. 1986; Otten et al. 1992). To our knowledge, this study is the first to report mucosal antibodies against citrullinated peptides in RA. Although we did not explicitly determine whether the salivary IgA antiCCP antibodies were di- or polymeric molecules containing joining chain and secretory component, it is known that the two dominating immunoglobulins in saliva are secretory IgA produced locally by salivary glands and IgG derived from the circulation (Brandtzaeg 2007). Further, transfer of anti-CCP antibodies from the circulation to saliva was unlikely in the present study as no $\lg G$ anti-CCP reactivity was recorded in saliva, apart from one case with a high serum level (2000 IU/mL) and a borderline positive salivary test. In addition, the presence of salivary IgA antiCCP was not significantly different between serum IgA-CCP positive and negative patients, thus strongly arguing against the possibility that salivary IgA-class antibodies merely reflected the systemic compartment.

From studies on experimental autoimmune diseases, including collagen type II (CII) induced arthritis (CIA), systemic tolerance after mucosal immunisation with autoantigen is well-known (Weiner et al. 2011). CIA in mice, including 'humanised' animals transgenic for HLA-DRB1/shared epitope (SE) (Bäcklund et al. 2003), are still prevailing experimental models for RA. Based upon such experimental settings, it was long suspected that systemic immunisation against $\mathrm{Cll}$ is crucial also for the development of RA in man. In support of this, as well as of the possibility to downregulate an established systemic immune response against CII, a study from 1991 reported that oral treatment with chicken Cll was efficient in RA (Trentham et al. 
1993). However, the initial high expectations on oral Cll as a tolerogenic agent for RA have not been met (Toussirot 2002). In retrospect, the lack of success regarding oral tolerance induction with $\mathrm{Cll}$ in RA is not surprising, since autoimmunity to $\mathrm{Cll}$ does not seem to be the clue to RA aetiopathogenesis. Anti-CII antibodies have low diagnostic specificity for RA and occur in a minority of RA patients, which are predominantly ACPA-negative and have a favourable prognosis (Mullazehi et al. 2007; Raza et al. 2008). Yet, systemic immunisation against citrullinated Cll may be relevant in relation to RA pathogenesis (Lundberg et al. 2005; Uysal et al. 2009). There are several lines of evidence that ACPA seropositive and ACPA seronegative RA have distinct aetiopathogenetic features. For instance, it is well established that a combination of cigarette smoking and genetic carriage of HLA-DRB1/SE is a strong risk of developing IgG-ACPA positive, but not IgG-ACPA negative, RA (Morgan et al. 2009; Padyukov et al. 2011). Although derived from studies of much smaller format, there are indications of serum IgA-ACPA being even more strongly related to smoking but not to SE (Verpoort et al. 2007; Svärd et al. 2010) and Kokkonen et al showed that smoking pre-RA patients developed circulating IgA-CCP earlier than did their non-smoking counterparts (Kokkonen et al. 2011).

The possible connection between periodontal disease and RA has recently gained renewed interest. The fact that Porphyromonas gingivalis $(\mathrm{Pg})$ has enzymatic peptide-citrullinating capacity has led to the hypothesis that, in susceptible individuals, this oral pathogen may evoke a systemic immune response leading to RA (McGraw et al. 1999; Rosenstein et al. 2004; Mikuls et al. 2009; Hitchon et al. 2010; Lundberg et al. 2010). In the present study, information on oral health status and anti- $P g$ antibodies was not available. Future prospective clinical studies, preferably in 
pre-RA patients, should aim at investigating circulating as well as mucosal antibodies to native $P g$ antigens and to citrullinated antigens in relation to smoking, genetic risk alleles, and RA development.

Although demonstration of salivary slgA antibodies does not necessarily reflect immunisation at other mucosal compartments, and despite the many obstacles regarding salivary antibody analysis (Brandtzaeg 2007), saliva is a convenient and relevant possibility to evaluate mucosal immunisation. Our indications of a less severe disease in patients with salivary $\lg A-A C P A$, point at citrullinated antigens as a more rational means than oral $\mathrm{CII}$ to induce systemic tolerance for RA primary prevention and/or, possibly, immunodeviation of an established systemic immune response against citrullinated antigen. The prevalence rate of salivary IgA anti-CCP antibodies (22\% of RA patients) shown in this study, must be interpreted precautiously, since the cases were largely selected on the basis of positive serum $\lg \mathrm{G}$ anti-CCP tests. Once the occurrence of mucosal $\lg \mathrm{A}$ anti-CCP antibodies now has been demonstrated in this pilot study, we advocate that future studies should be performed on larger patient and reference populations without bias from previous serological results and with structured follow-up data regarding disease course and radiological outcome.

Based on our findings in the present study we hypothesise that primary mucosal immunisation against citrullinated peptides may have a systemic tolerance-inducing ability and that mucosal immunisation with formation of secretory IgA-ACPA in patients with established IgG-ACPA positive arthritis may possibly have an immunedeviating/disease-modifying effect. Whether or not mucosal immunisation against 
citrullinated antigens occurs in healthy individuals is an important issue calling for future studies. If this is the case, identification of natural sources of tolerogenic citrullinated peptides (autoantigens? dietary? microbial?) is another subject of interest. Furthermore, development of therapeutic oral citrullinated antigens is challenging and perhaps a more fruitful approach than mucosal immunisation with native type II collagen.

From previous studies we know that the presence of circulating IgA-ACPA relates to a more aggressive disease (Verpoort et al. 2006; Svärd et al. 2008; Svärd et al. 2010). However, a systemic IgA-response could reflect a means to competitively inhibit excessive pro-inflammatory IgG-mediated effects via activating $\mathrm{F} c \gamma$ receptors on synovial macrophages and/or classical complement activation. Apart from antiinflammatory beneficial immune responses, the concept of proinflammatory/dysregulated immune responses against antigens on mucosal surfaces is an old and frequently revitalised hypothesis as regards cross-talk with joints and pathogenesis of arthritis (Olhagen et al. 1968; Doube et al. 1988; Trollmo et al. 1994; Scheinecker et al. 2011). In the present study, we found no correlation between the occurrence of salivary and circulating IgA anti-CCP antibodies, supporting the notion that salivary IgA is essentially derived from salivary gland plasma cells (Brandtzaeg 2007) and that circulating monomeric IgA-class antibodies, i.e, the bulk of circulating IgA, are produced independently of mucosal slgA antibodies (Russell et al. 2010).

To conclude, IgA anti-CCP can be detected in saliva from a proportion of RA patients and may be associated with a milder disease course and outcome. 


\section{ACKNOWLEDGEMENTS}

This study was financed by the Centre for Clinical Research in Dalarna and by grants from the Swedish Research Council (2008-2832), the Swedish association against Rheumatism, king Gustaf Vth 80-year foundation, the County Council of Östergötland research foundations, and the Medical Research County Council of South-East Sweden (FORSS). The funding sources had no involvement in the study design, writing the report or in the decision to submit the paper for publication. 


\section{REFERENCES}

Aletaha, D., Neogi, T., Silman, A. J., Funovits, J., Felson, D. T., Bingham, C. O., Birnbaum, N. S., Burmester, G. R., Bykerk, V. P., Cohen, M. D., et al. 2010. 2010 Rheumatoid arthritis classification criteria: An American College of Rheumatology/European League Against Rheumatism collaborative initiative. Arthritis \& Rheumatism 62: 2569.

Arnett, F. C., Edworthy, S. M., Bloch, D. A., McShane, D. J., Fries, J. F., Cooper, N. S., Healey, L. A., Kaplan, S. R., Liang, M. H., Luthra, H. S., et al. 1988. The American Rheumatism Association 1987 revised criteria for the classification of rheumatoid arthritis. Arthritis Rheum 31: 315.

Bäcklund, J., Nandakumar, K. S., Bockermann, R., Mori, L., and Holmdahl, R. 2003. Genetic Control of Tolerance to Type II Collagen and Development of Arthritis in an Autologous Collagen-Induced Arthritis Model. The Journal of Immunology 171: 3493.

Baumgarth, N. 2011. The double life of a B-1 cell: self-reactivity selects for protective effector functions. Nat Rev Immunol 11: 34.

Berglin, E., Johansson, T., Sundin, U., Jidell, E., Wadell, G., Hallmans, G., and Rantapää-Dahlqvist, S. 2006. Radiological outcome in rheumatoid arthritis is predicted by presence of antibodies against cyclic citrullinated peptide before and at disease onset, and by IgA-RF at disease onset. Ann Rheum Dis 65: 453.

Brandtzaeg, P. 2007. Do Salivary Antibodies Reliably Reflect Both Mucosal and Systemic Immunity? Annals of the New York Academy of Sciences 1098: 288.

Brandtzaeg, P. 2010. Function of Mucosa-Associated Lymphoid Tissue in Antibody Formation. Immunological Investigations 39: 303.

Cerutti, A., Chen, K., and Chorny, A. 2011. Immunoglobulin Responses at the Mucosal Interface. Annual Review of Immunology 29: 273.

Chase, M. W. 1946. Inhibition of experimental drug allergy by prior feeding of the sensitizing agent. Proc Soc Exp Biol Med 61: 257.

Chu, J. L., Gharavi, A. E., and Elkon, K. B. 1986. Spectrotypic analysis of IgM and IgA rheumatoid factors. Clin Exp Immunol 63: 601.

Doube, A., and Collins, A. J. 1988. Is the gut intrinsically abnormal in rheumatoid arthritis? Ann Rheum Dis 47: 617.

Dunne, J. V., Carson, D. A., Spiegelberg, H. L., Alspaugh, M. A., and Vaughan, J. H. 1979. IgA rheumatoid factor in the sera and saliva of patients with rheumatoid arthritis and Sjogren's syndrome. Ann Rheum Dis 38: 161.

Ekdahl, C., Eberhardt, K., Andersson, S. I., and Svensson, B. 1988. Assessing disability in patients with rheumatoid arthritis. Use of a Swedish version of the Stanford Health Assessment Questionnaire. Scand J Rheumatol 17: 263.

Elkon KB, G. A., Patel BM, Hughes GRV, Frankel A. . 1983. IgA and IgM rheumatoid factors in serum, saliva and other secretions: relationship to immunoglobulin ratios in systemic sicca syndrome and rheumatoid arthritis. . Clin. exp. Immunol 52: 75.

Forslind, K., Ahlmen, M., Eberhardt, K., Hafström, I., and Svensson, B. 2004. Prediction of radiological outcome in early rheumatoid arthritis in clinical practice: role of antibodies to citrullinated peptides (anti-CCP). Ann Rheum Dis 63: 1090. 
Hitchon, C. A., Chandad, F., Ferucci, E. D., Willemze, A., loan-Facsinay, A., van der Woude, D., Markland, J., Robinson, D., Elias, B., Newkirk, M., et al. 2010. Antibodies to Porphyromonas gingivalis Are Associated with Anticitrullinated Protein Antibodies in Patients with Rheumatoid Arthritis and Their Relatives. The Journal of Rheumatology 37: 1105.

Houssien, D. A., Jonsson, T., Davies, E., and Scott, D. L. 1997. Clinical significance of $\lg A$ rheumatoid factor subclasses in rheumatoid arthritis. J Rheumatol 24: 2119.

Huizinga, T. W., Amos, C. I., van der Helm-van Mil, A. H., Chen, W., van Gaalen, F. A., Jawaheer, D., Schreuder, G. M., Wener, M., Breedveld, F. C., Ahmad, N., et al. 2005. Refining the complex rheumatoid arthritis phenotype based on specificity of the HLA-DRB1 shared epitope for antibodies to citrullinated proteins. Arthritis Rheum 52: 3433.

Kastbom, A., Strandberg, G., Lindroos, A., and Skogh, T. 2004. Anti-CCP antibody test predicts the disease course during 3 years in early rheumatoid arthritis (the Swedish TIRA project). Ann Rheum Dis 63: 1085.

Kokkonen, H., Mullazehi, M., Berglin, E., Hallmans, G., Wadell, G., Rönnelid, J., and Rantapää-Dahlqvist, S. 2011. Antibodies of $\lg G, \lg A$ and $\lg M$ isotypes against cyclic citrullinated peptide precede the development of rheumatoid arthritis. Arthritis Research \& Therapy 13: R13.

Lindqvist, E., Eberhardt, K., Bendtzen, K., Heinegard, D., and Saxne, T. 2005. Prognostic laboratory markers of joint damage in rheumatoid arthritis. Ann Rheum Dis 64: 196.

Lundberg, K., Nijenhuis, S., Vossenaar, E. R., Palmblad, K., van Venrooij, W. J., Klareskog, L., Zendman, A. J., and Harris, H. E. 2005. Citrullinated proteins have increased immunogenicity and arthritogenicity and their presence in arthritic joints correlates with disease severity. Arthritis Res Ther 7: R458.

Lundberg, K., Wegner, N., Yucel-Lindberg, T., and Venables, P. J. 2010. Periodontitis in RA[mdash]the citrullinated enolase connection. Nat Rev Rheumatol 6: 727.

McGraw, W. T., Potempa, J., Farley, D., and Travis, J. 1999. Purification, Characterization, and Sequence Analysis of a Potential Virulence Factor from Porphyromonas gingivalis, Peptidylarginine Deiminase. Infect. Immun. 67: 3248.

Mestecky, J., Russell, M. W., and Elson, C. O. 2007. Perspectives on Mucosal Vaccines: Is Mucosal Tolerance a Barrier? The Journal of Immunology 179: 5633.

Mikuls, T., Payne, J., Reinhardt, R., Thiele, G., Maziarz, E., Cannella, A., Holers, V., Kuhn, K., and O'Dell, J. 2009. Antibody responses to Porphyromonas gingivalis ( $P$. gingivalis) in subjects with rheumatoid arthritis and periodontitis. Int Immunopharmacol 9: 38

Morgan, A. W., Thomson, W., Martin, S. G., Yorkshire Early Arthritis Register, C., Carter, A. M., Consortium, U. K. R. A. G., Erlich, H. A., Barton, A., Hocking, L., Reid, D. M., et al. 2009. Reevaluation of the interaction between HLA-DRB1 shared epitope alleles, PTPN22, and smoking in determining susceptibility to autoantibody-positive and autoantibody-negative rheumatoid arthritis in a large UK Caucasian population. Arthritis \& Rheumatism 60: 2565.

Mullazehi, M., Mathsson, L., Lampa, J., and Rönnelid, J. 2007. High anti-collagen type-Il antibody levels and induction of proinflammatory cytokines by anticollagen antibody-containing immune complexes in vitro characterise a distinct 
rheumatoid arthritis phenotype associated with acute inflammation at the time of disease onset. Annals of the Rheumatic Diseases 66: 537.

Olhagen, B., and Månsson, I. 1968. Intestinal Clostridium perfringens in rheumatoid arthritis and other collagen diseases. Acta medica Scandinavica 184: 395.

Otten, H. G., Daha, M. R., van der Maarl, M. G., Hoogendoorn, L. I., Beem, E. M., de Rooy, H. H., and Breedveld, F. C. 1992. IgA rheumatoid factor in mucosal fluids and serum of patients with rheumatoid arthritis: immunological aspects and clinical significance. Clin Exp Immunol 90: 256.

Padyukov, L., Seielstad, M., Ong, R. T., Ding, B., Rönnelid, J., Seddighzadeh, M., Alfredsson, L., Klareskog, L., and Group, t. E. I. o. R. A. S. 2011. Epidemiological Investigation of Rheumatoid Arthritis (EIRA) Study Group: A genome-wide association study suggests contrasting associations in ACPApositive versus ACPA-negative rheumatoid arthritis. Annals of the Rheumatic Diseases 70: 259.

Prevoo, M. L., van 't Hof, M. A., Kuper, H. H., van Leeuwen, M. A., van de Putte, L. B., and van Riel, P. L. 1995. Modified disease activity scores that include twenty-eight-joint counts. Development and validation in a prospective longitudinal study of patients with rheumatoid arthritis. Arthritis Rheum 38: 44.

Raza, K., Mullazehi, M., Salmon, M., Buckley, C. D., and Rönnelid, J. 2008. Anticollagen type II antibodies in patients with very early synovitis. Ann Rheum Dis 67: 1354.

Rosenstein, E., Greenwald, R., Kushner, L., and Weissmann, G. 2004. Hypothesis: The Humoral Immune Response to Oral Bacteria Provides a Stimulus for the Development of Rheumatoid Arthritis. Inflammation 28: 311.

Russell, M. W., and Ogra, P. L. 2010. Mucosal Decisions: Tolerance and Responsiveness at Mucosal Surfaces. Immunological Investigations 39: 297.

Scheinecker, C., and Smolen, J. S. 2011. Rheumatoid arthritis in 2010: From the gut to the joint. Nat Rev Rheumatol 7: 73.

Skogh, T. 1982. Overestimate of 125I-protein uptake from the adult mouse gut. Gut 23: 1077.

Skogh, T., Edebo, L., and Stendahl, O. 1983. Gastrointestinal uptake and blood clearance of antigen in the presence of $\lg A$ antibodies. Immunology 50: 175.

Stokes, C. R., Soothill, J. F., and Turner, M. W. 1975. Immune exclusion is a function of IgA. Nature 255: 745.

Suzuki, K., Maruya, M., Kawamoto, S., and Fagarasan, S. 2010. Roles of B-1 and B2 cells in innate and acquired IgA-mediated immunity. Immunological Reviews 237: 180.

Svärd, A., Kastbom, A., Reckner-Olsson, A., and Skogh, T. 2008. Presence and utility of IgA-class antibodies to cyclic citrullinated peptides in early rheumatoid arthritis: the Swedish TIRA project. Arthritis Res Ther 10: R75.

Svärd, A., Kastbom, A., Söderlin, M. K., Reckner-Olsson, A., and Skogh, T. 2010. A Comparison Between IgG- and IgA-class Antibodies to Cyclic Citrullinated Peptides and to Modified Citrullinated Vimentin in Early Rheumatoid Arthritis and Very Early Arthritis. J Rheumatol 38: 1265.

Toussirot, E. A. 2002. Oral tolerance in the treatment of rheumatoid arthritis. Curr Drug Targets Inflamm Allergy 1: 45.

Trentham, D. E., Dynesius-Trentham, R. A., Orav, E. J., Combitchi, D., Lorenzo, C., Sewell, K. L., Hafler, D. A., and Weiner, H. L. 1993. Effects of oral administration of type II collagen on rheumatoid arthritis. Science 261: 1727. 
Trollmo, C., Sollerman, C., Carlsten, H., and Tarkowski, A. 1994. The gut as an inductive site for synovial and extra-articular immune responses in rheumatoid arthritis. Ann Rheum Dis 53: 377.

Uysal, H., Bockermann, R., Nandakumar, K. S., Sehnert, B., Bajtner, E., Engström, A., Serre, G., Burkhardt, H., Thunnissen, M. M. G. M., and Holmdahl, R. 2009. Structure and pathogenicity of antibodies specific for citrullinated collagen type II in experimental arthritis. The Journal of Experimental Medicine 206: 449.

van der Woude, D., Rantapää-Dahlqvist, S., loan-Facsinay, A., Onnekink, C., Schwarte, C. M., Verpoort, K. N., Drijfhout, J. W., Huizinga, T. W., Toes, R. E., and Pruijn, G. J. 2010. Epitope spreading of the anti-citrullinated protein antibody response occurs before disease onset and is associated with the disease course of early arthritis. Ann Rheum Dis 69: 1554.

van Gaalen, F. A., Linn-Rasker, S. P., van Venrooij, W. J., de Jong, B. A., Breedveld, F. C., Verweij, C. L., Toes, R. E., and Huizinga, T. W. 2004. Autoantibodies to cyclic citrullinated peptides predict progression to rheumatoid arthritis in patients with undifferentiated arthritis: a prospective cohort study. Arthritis Rheum 50: 709.

Weiner, H. L., da Cunha, A. P., Quintana, F., and Wu, H. 2011. Oral tolerance. Immunological Reviews 241: 241.

Verpoort, K. N., Jol-van der Zijde, C. M., Papendrecht-van der Voort, E. A., loanFacsinay, A., Drijfhout, J. W., van Tol, M. J., Breedveld, F. C., Huizinga, T. W., and Toes, R. E. 2006. Isotype distribution of anti-cyclic citrullinated peptide antibodies in undifferentiated arthritis and rheumatoid arthritis reflects an ongoing immune response. Arthritis Rheum 54: 3799.

Verpoort, K. N., Papendrecht-van der Voort, E. A., van der Helm-van Mil, A. H., Jolvan der Zijde, C. M., van Tol, M. J., Drijfhout, J. W., Breedveld, F. C., de Vries, R. R., Huizinga, T. W., and Toes, R. E. 2007. Association of smoking with the constitution of the anti-cyclic citrullinated peptide response in the absence of HLA-DRB1 shared epitope alleles. Arthritis Rheum 56: 2913. 


\section{Figure legends}

Figure 1

Examples of two representative inhibition experiments with soluble citrullinated peptide (CCP) and cyclic arginine peptide (CAP). In salivary samples with an antiCCP/anti-CAP ratio of $>1.5$, soluble CCP (but not soluble CAP) inhibited the autoantibody enzyme immunoassay in a dose-dependent manner $(A)$. No inhibition was seen in samples with anti-CCP/anti-CAP ratios $\leq 1.5(B)$.

Figure 2

Illustration showing how pre-incubation with soluble cyclic citrullinated peptide (CCP) at a concentration of $800 \mu \mathrm{g} / \mathrm{mL}$ inhibits salivary $\lg A$ anti-CCP reactivity depending on the level of salivary antibodies. A positive $\lg A$ anti-CCP test is defined as a ratio $>1.5$ achieved by dividing the results of an anti-CCP enzyme immunoassay (EIA) with the results obtained with an EIA using the control peptide 'cyclic arginine peptide' (CAP) as antigen.

\section{Figure 3}

Diagram to illustrate disease activity reflected by median levels of erythrocyte sedimentation rate (ESR) and serum C-reactive protein (CRP) at diagnosis of rheumatoid arthritis, and radiologic outcome in hands and feet within 6 years in relation to the occurrence of salivary $\lg A$ antibodies against cyclic citrullinated peptides (CCP). Antibodies against cyclic arginine peptide (CAP) served as control. $A$ positive anti-CCP test is defined as an anti-CCP/anti-CAP ratio $>1.5$. 
Figure 1

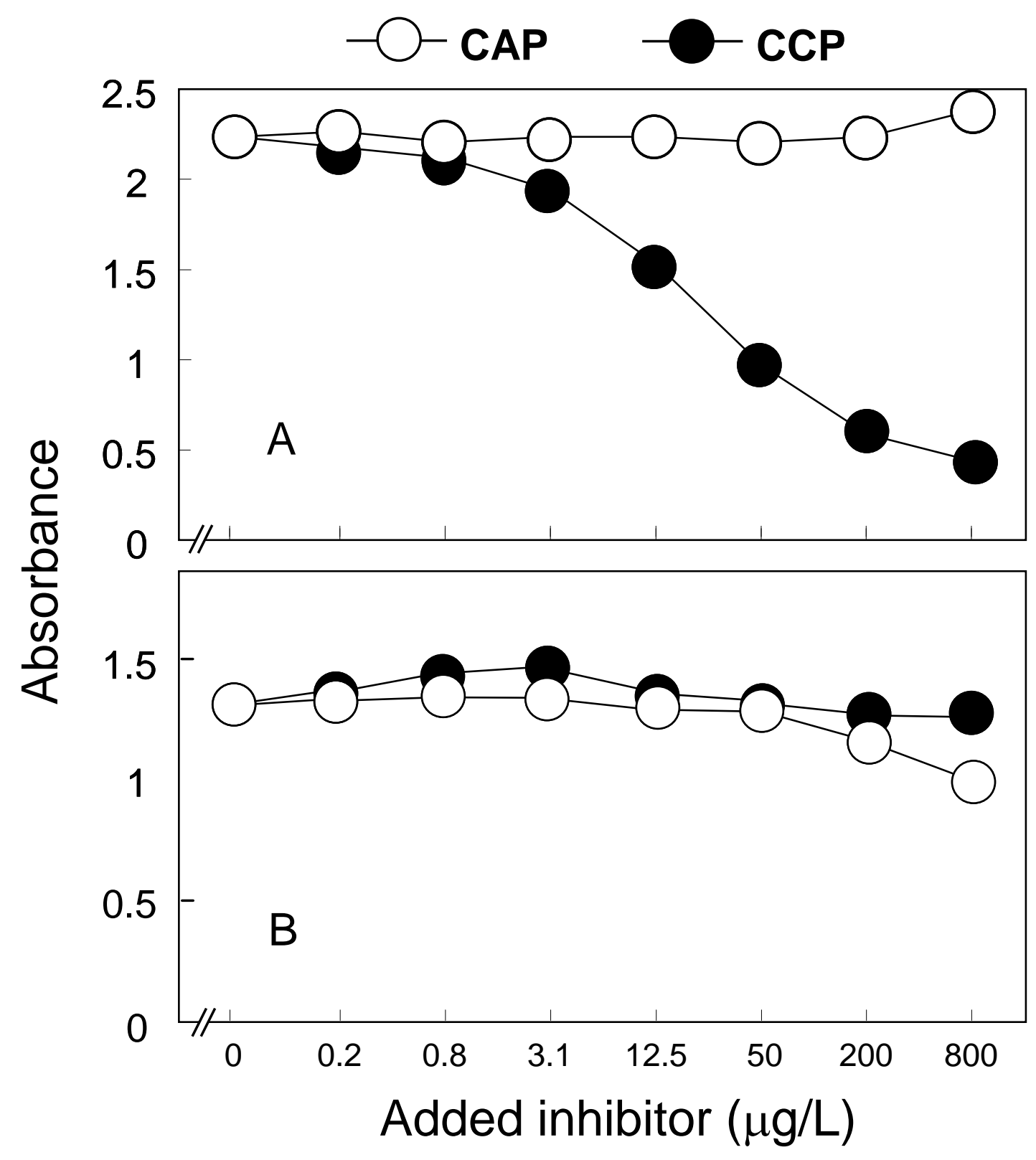


Figure 2

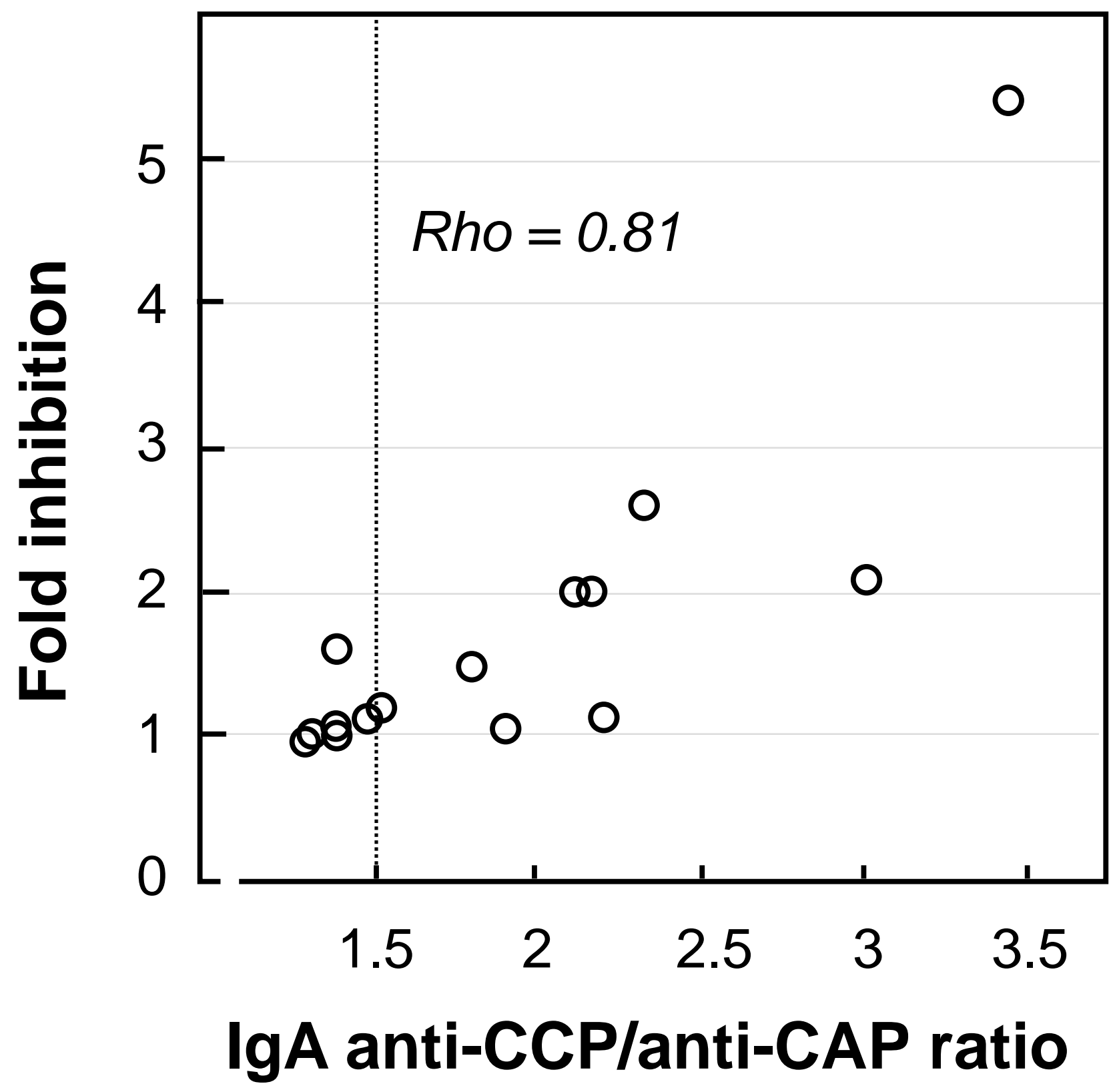


Figure 3

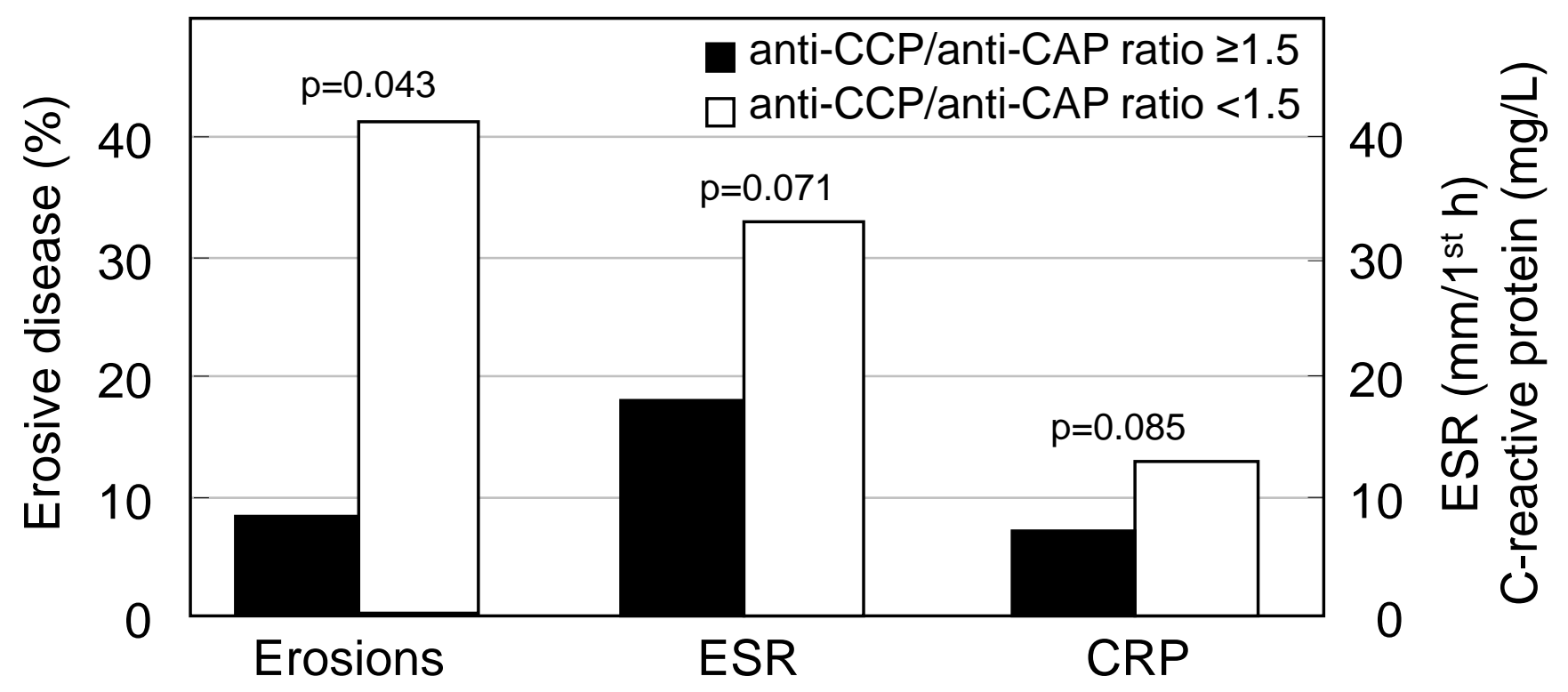


Table 1. Characteristics of rheumatoid arthritis patients at inclusion.

\begin{tabular}{|lccc|}
\hline & $\begin{array}{c}\text { slgA }^{1} \text { anti-CCP+ } \\
(\mathrm{n}=14)\end{array}$ & $\mathrm{P}$ & $\begin{array}{c}{ }^{2} \\
\text { sigA anti-CCP- } \\
(\mathrm{n}=49)\end{array}$ \\
\hline Median age (range) & $66(39-75)$ & $\mathrm{ns}^{3}$ & $62(30-84)$ \\
Proportion women & $64 \%$ & $\mathrm{~ns}$ & $69 \%$ \\
Methotrexate treatment & $79 \%$ & $\mathrm{~ns}$ & 71 \\
DMARD ${ }^{3}$ combination with or without biologics & $50 \%$ & $\mathrm{~ns}$ & 35 \\
Serum RF (proportion positive) & $92 \%$ & $\mathrm{~ns}$ & $73 \%$ \\
Serum RF (IU/mL), median among RF ${ }^{5}$-positive cases & $200(\mathrm{n}=12)$ & $\mathrm{ns}$ & $100(\mathrm{n}=33)$ \\
Serum IgG anti-CCP (proportion positive) & $100 \%$ & $\mathrm{~ns}$ & $80 \%$ \\
Serum IgG anti-CCP (U/mL), median among positive cases & $800(\mathrm{n}=9)$ & $\mathrm{ns}$ & $500(\mathrm{n}=33)$ \\
Serum IgA anti-CCP (proportion positive) & $50 \%$ & $\mathrm{~ns}$ & $28 \%$ \\
Serum IgA anti-CCP (AU/mL), median among positive cases & $55(\mathrm{n}=4)$ & $\mathrm{ns}$ & $53(\mathrm{n}=10)$ \\
\hline
\end{tabular}

$\begin{array}{lll}\text { 1. secretory (salivary) immunoglobulin A } & \text { 2. } C C P=\text { cyclic citrullinated peptide } 3 . n s=\text { not significant }\end{array}$

4. $\mathrm{DMARD}=$ disease-modifying anti-rheumatic drug $\quad 5 . \mathrm{RF}=$ particle-agglutinating rheumatoid factor 